\title{
Genetic analysis of subclinical mastitis in early lactation of heifers using both linear and threshold models
}

\author{
Saranya G. Narayana, ${ }^{*} \dagger \ddagger^{1}$ Filippo Miglior, $\dagger \ddagger \S$ S. Ali Naqvi, ${ }^{\ddagger} \ddagger$ Francesca Malchiodi, $\dagger$ Pauline Martin, $\dagger \#$ \\ and Herman W. Barkema*† \\ *Department of Production Animal Health, Faculty of Veterinary Medicine, University of Calgary, Calgary, AB, Canada, T2N 1N4 \\ †Centre for Genetic Improvement of Livestock, Department of Animal Biosciences, University of Guelph, Guelph, ON, Canada, N1G 2W1 \\ †Canadian Bovine Mastitis and Milk Quality Research Network, St-Hyacinthe, QC, J2S 7C6, Canada \\ $\S$ Canadian Dairy Network, Guelph, ON, Canada, N1K 1E5 \\ \#Génétique Animale et Biologie Intégrative (GABI), Institut National de la Recherche Agronomique (INRA), AgroParisTech, \\ Université Paris-Saclay, 78352 Jouy-en-Josas, France
}

\begin{abstract}
Subclinical mastitis (SCM) causes economic losses for dairy producers by reducing milk production and leading to higher incidence of clinical mastitis and premature culling. The prevalence of SCM in first-lactation heifers is highest during early lactation. The objective of this study was to estimate genetic parameters for SCM in early lactation in first-parity Holsteins. Somatic cell count test-day records were collected monthly in 91 Canadian herds participating in the National Cohort of Dairy Farms of the Canadian Bovine Mastitis Research Network. Only the first test-day record available between 5 and $30 \mathrm{~d}$ in milk was considered for analysis. The final data set contained 8,518 records from first lactation Holstein heifers. Six alternative traits were defined as indicators of SCM, using various cutoff values of SCC, ranging from 150,000 to 400,000 cells/mL. Both linear and threshold animal models were used. Overall prevalence of SCM using the 6 traits ranged from 13 to $24 \%$. Heritability estimates (standard error) from linear and threshold models ranged from 0.037 to 0.057 (0.015 to 0.018) and from 0.040 to 0.051 (0.017 to 0.020 ), respectively. We found strong genetic correlations (standard error) among alternative SCC traits, ranging from 0.90 to 0.99 (0.013 to 0.069), indicating that these 6 traits were genetically similar. Despite low heritability, based on estimated breeding values (EBV) predicted from both models, we noted exploitable genetic variation among sires. Higher EBV of SCM resistance corresponded to sires with a higher percentage of daughters without SCM. Based on a linear model (all 6 traits), percentage of daughters with SCM ranged from 5 to $13 \%$ and from 19 to $33 \%$ for the top $10 \%$ and worst $10 \%$ of 69 sires with minimum 20 daughters in at least
\end{abstract}

Received May 29, 2018.

Accepted August 21, 2018.

${ }^{1}$ Corresponding author: saranya.narayana@ucalgary.ca
5 herds, respectively. Spearman's rank correlations among EBV of sires predicted from linear (from 0.75 to 0.95 ) and threshold (from 0.74 to 0.95 ) models were moderate to high, respectively. Very high rank correlations (0.98 to 0.99) between EBV predicted for the same trait from linear and threshold model indicated that reranking of sires based on model used was minimal. In conclusion, despite low heritability, we found utilizable genetic variation in early lactation of heifers. Hence, genetic selection to improve genetic resistance to SCM in early lactation of heifers was deemed possible.

Key words: mastitis, somatic cell count, early lactation, genetic evaluation

\section{INTRODUCTION}

Mastitis is one of the most prominent and costly diseases of dairy cattle (Hortet et al., 1999; Koeck et al., 2012a; Saidi et al., 2013). Mastitis is an IMI that causes udder inflammation, abnormalities in the milk, reduced milk production, and a high incidence of involuntary culling (Halasa et al., 2007). Cows with subclinical mastitis (SCM), defined as SCC exceeding a cutoff value, do not have any physical abnormalities (Saidi et al., 2013), but have decreased milk production, undesirable changes in milk composition, and inflammatory components in milk (Heringstad et al., 2000). Moreover, increased prevalence of SCM is associated with a higher incidence of clinical mastitis (Rupp et al., 2000; Steeneveld et al., 2008), which can result in involuntary culling and consequently has a great economic impact. Herd-level economic losses caused by SCM are substantial and even exceed those caused by clinical mastitis (Huijps et al., 2008). The main economic loss associated with SCM is milk loss. De Vliegher et al. (2005) reported that early in the first lactation (5 to 14 DIM), a 1-unit increase in natural log-transformed SCC was associated with decrease in $0.13 \mathrm{~kg} / \mathrm{d}$ of milk yield later in lactation. 
Elevated SCC is commonly used to detect SCM (Harmon, 1994; Pyörälä, 2003). However, the SCC cutoff for definition of SCM is not uniform; therefore, prevalence of SCM is not consistent across studies. The threshold of SCC used to classify SCM ranges from 100,000 to 500,000 cells $/ \mathrm{mL}$, with 200,000 cells $/ \mathrm{mL}$ being the most widely used cutoff (Svendsen and Heringstad., 2006; Halasa et al., 2009; Koeck et al., 2012b). The reported prevalence of SCM ranges from 11 to $52 \%$ (Gianneechini et al., 2002; Svendsen and Heringstad, 2006; Santman-Berends and Sampimon, 2011).

In first-lactation heifers, SCM prevalence is highest in early lactation and is associated with increased SCC throughout the first lactation (De Vliegher et al., 2004). Koeck et al. (2012a) reported that $35 \%$ of CM occurred during the first month after calving, perhaps a consequence of not detecting SCM. The high prevalence of SCM in early lactation is mainly attributed to unresolved IMI before the first calving (Trinidad et al., 1990) and less frequently to a new IMI. Hence, breeding for heifers less susceptible to SCM, in combination with efficient management practices, is a sustainable strategy to prevent and control mastitis. Some genetic studies have regarded SCM as a binary trait (Koivula et al., 2004; Svendsen and Heringstad, 2006; De Haas et al., 2008; Urioste et al., 2012). Most genetic studies have focused on mean lactational SCC and SCS (Shook and Schutz, 1994; Koeck et al., 2012b; Alam et al., 2015). Reported heritability of SCM ranges from 0.03 to 0.17 (Koivula et al., 2004; Svendsen and Heringstad, 2006; De Haas et al., 2008; Urioste et al., 2012); however, as the definition of SCM varies, it is difficult to compare genetic parameters across studies. Moreover, genetic studies on SCM that focus on early lactation in heifers are very scarce. Objectives of our study were to (1) estimate genetic parameters for SCM in Canadian Holstein heifers in early lactation using alternative definitions of SCM based on test-day SCC; and (2) compare heritabilities and EBV for SCM resistance obtained from both threshold and linear models.

\section{MATERIALS AND METHODS}

\section{Data}

Rationale and details regarding selection of farms were described previously (Reyher et al., 2011). Briefly, testday records for SCC were collected monthly between 2005 and 2009 in 91 Canadian dairy herds participating in the National Cohort of Dairy Farms of the Canadian Bovine Mastitis Research Network (St-Hyacinthe, QC, Canada). To represent inherent diversity of Canadian dairy herds, commercial dairy farms were selected from 6 provinces: Alberta, Ontario, Québec, Prince Edward
Island, Nova Scotia, and New Brunswick. All participating herds had $>80 \%$ Holstein cows, milked twice per day, and participated in a regular DHI recording system.

The initial data set contained 352,101 records of 19,319 Holstein cattle from 91 Canadian dairy herds. For genetic analysis, herds were required to have a minimum of 50 lactating females. Test-day records from first-lactation Holstein heifers with an age at first calving from 18 to 36 mo were considered. Only the first test-day record available between 5 to 30 DIM was included in analyses. The final data set contained records from 8,518 Holstein first-lactation heifers from 90 herds; however, the pedigree file contained a total of 43,344 animals, generated by tracing back 7 generations.

\section{Trait Definition}

Six traits were defined as an indicator of SCM based on SCC in composite DHI milk samples. All traits were coded as binary variables ( 0 or 1 ), with 1 assigned to the presence of SCM. For the first 3 traits, SCC cutoff values of $150,000,200,000$ and 250,000 cells $/ \mathrm{mL}$ from $5 \leq \mathrm{DIM} \leq 30$ were used $\left(\mathbf{S C M}_{150}, \mathbf{S C M}_{\mathbf{2 0 0}}\right.$, and $\mathbf{S C M}{ }_{250}$, respectively). Heifers with SCC exceeding cutoffs were considered affected (1), with all other heifers designated healthy (0). For the latter 3 traits, heifers were considered affected (1) if SCC $>400,000$ cells $/ \mathrm{mL}$ within $5 \leq \mathrm{DIM} \leq 10$ and $\mathrm{SCC}$ was $>150,000$, 200,000, and 250,000 cells/mL (namely, $\mathbf{S C M}_{400,150}$, $\mathbf{S C M}_{400,200}$, and $\mathbf{S C M}_{400,250}$, respectively) within 11 $\leq \mathrm{DIM} \leq 30$. Different thresholds for different periods of DIM were used to account for dilution effect and fluctuation due to DIM (Miller et al., 1993; Harmon, 1994; Schepers et al., 1997); a similar approach was used by Koeck et al. (2012b). Thresholds and intervals were selected based on mean SCC distribution from 5 to 30 DIM (Figure 1b).

\section{Statistical Models}

Subclinical mastitis was analyzed using both linear and probit threshold models. In theory, threshold models are more appropriate for analysis of binary response traits, as they account for the binary nature of the data (Gianola, 1982; Gianola and Foulley, 1983). Existence of an underlying continuous nonobservable variable, called liability $(\lambda)$ is assumed in a threshold-liability model. If the $\lambda$ is larger than a fixed threshold $(\tau)$, then the observed binary response takes the value of 1 , otherwise it is designated 0 .

Given the mean and variance, liability was assumed to be normally distributed. As threshold $(\tau)$ and the 

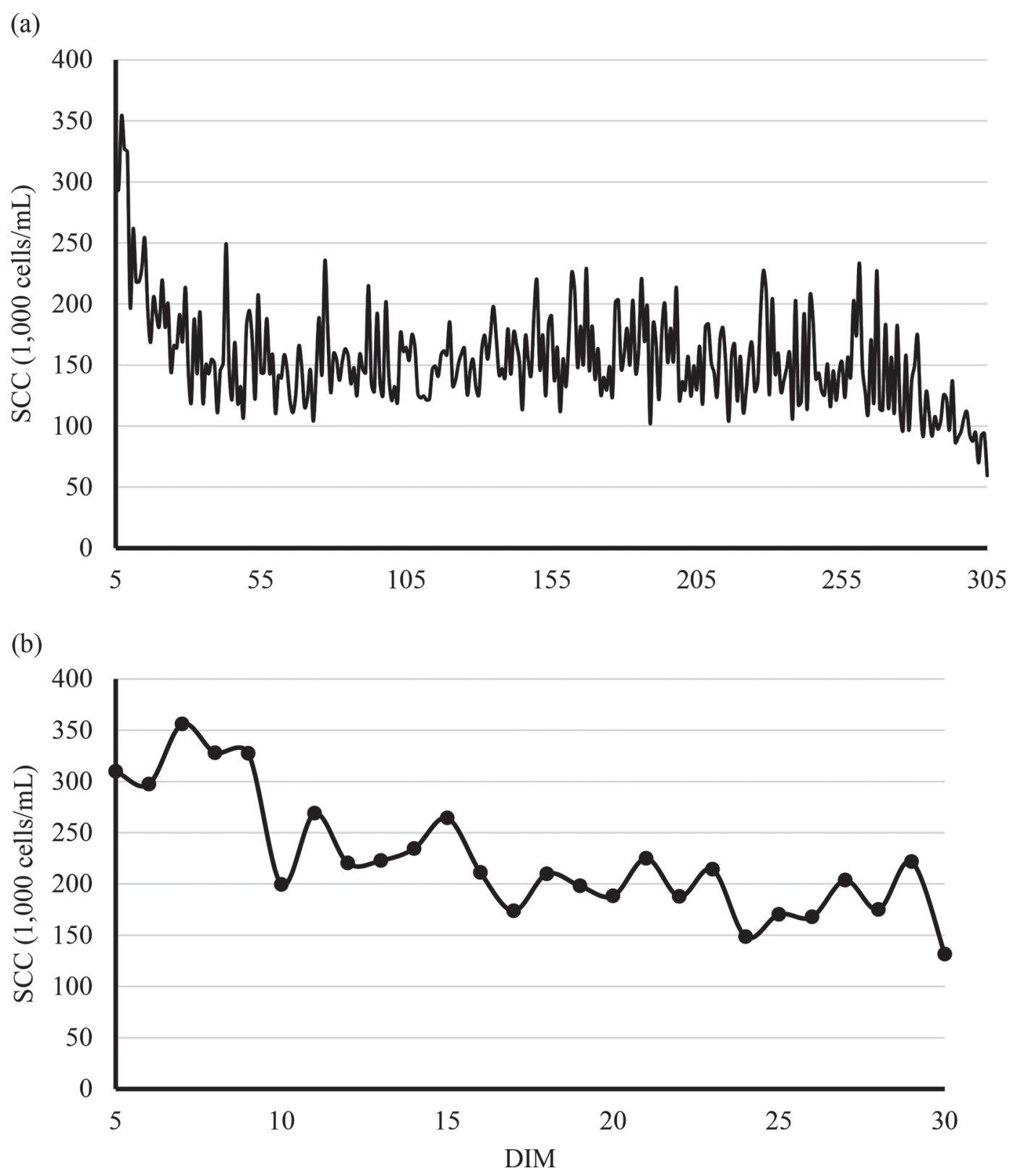

Figure 1. Mean SCC in first-lactation Holstein heifers from (a) 5 to 305 DIM and (b) from 5 to 30 DIM.

residual variance $\left(\sigma_{e}^{2}\right)$ were not identifiable, these parameters were assigned arbitrary values of 0 and 1 , respectively. When a linear model is used for analysis of binary data, heritability estimates change according to the frequency of the trait (Gianola, 1982). However, when the progeny group size is large, binary trait analyses using threshold linear models yield similar sire rankings with respect to single-trait genetic evaluation (Hagger and Hofer, 1990; Heringstad et al., 2003; Negussie et al., 2008). Therefore, linear models are of- ten implemented for routine genetic evaluation of binary traits.

Variance and covariance components were estimated using the REML procedure for linear models and generalized linear mixed models (GLMM) with a probit link function for the threshold model in ASReml (Gilmour et al., 2009). We used the probit link function $\mathrm{E}\left(\mathrm{y}_{\mathrm{n}}\right)=$ $\Phi\left(\lambda_{n}\right)$, where $\mathrm{E}\left(\lambda_{\mathrm{n}}\right)$ is the expected value for the $n$th observation (0 or 1$)$; $\Phi$ is the normal cumulative density function; and $\lambda_{\mathrm{n}}$ is $n$th fitted value on the underlying normal scale. 
The following linear model was applied to all SCM traits:

$$
\mathbf{y}=\mathbf{X} \boldsymbol{\beta}+\mathbf{Z}_{\mathrm{hy}} \mathbf{h y}+\mathbf{Z}_{\mathrm{a}} \mathbf{a}+\mathbf{e},
$$

where $\mathbf{y}$ is a vector of observations; $\boldsymbol{\beta}$ is a vector of systematic effects, including fixed effects for age at first calving (10 classes) and year-season of calving (20 classes); hy is a vector of random herd-year of calving effects (441 levels); a is a vector of random additive genetic animal effects (43,344 levels); e is a vector of random residuals; and $\mathbf{X}, \mathbf{Z}_{\mathrm{hy}}$, and $\mathbf{Z}_{\mathrm{a}}$ are corresponding incidence matrices. The linear model used in the current study was similar to the model used for genetic evaluation of mastitis in Canada (Jamrozik et al., 2013) and by Koeck et al. (2012b).

First and last classes of age at first calving were $<24$ and $>31$ mo, whereas other classes were single months. Year of calving classes were from $<2005$ to 2009 . Yearseason of calving classes were formed, from January 2005 to December 2009 by combining 3 consecutive months: January to March, April to June, July to September, and October to December.

Random effects were assumed to be normally distributed, with means equal to zero and covariance structure equal to

$$
v\left[\begin{array}{c}
\mathbf{h y} \\
\mathbf{a} \\
\mathbf{e}
\end{array}\right]=\left[\begin{array}{ccc}
\mathbf{I} \sigma_{h y}^{2} & 0 & 0 \\
0 & \mathbf{A} \sigma_{a}^{2} & 0 \\
0 & 0 & \mathbf{I} \sigma_{e}^{2}
\end{array}\right],
$$

where $\sigma_{h y}^{2}, \sigma_{a}^{2}$, and $\sigma_{e}^{2}$ are the herd-year of calving, animal additive genetic, and residual variances, respectively. $\mathbf{I}$ and $\mathbf{A}$ are the identity matrix and additive relationship matrix, respectively.

Subsequently, bivariate linear animal models were used to estimate phenotypic, genetic, and residual correlations between the 6 analyzed traits. Bivariate analyses using a threshold model were not performed, as similarity in estimated genetic correlations from linear and threshold models have been reported (Gianola, 1982; Negussie et al., 2008). Random effects were assumed to be normally distributed with mean equal to zero and a (co)variance structure as follows:

$$
v\left[\begin{array}{c}
\mathbf{h y} \\
\mathbf{a} \\
\mathbf{e}
\end{array}\right]=\left[\begin{array}{ccc}
\mathbf{H Y} \otimes \mathbf{I} & 0 & 0 \\
0 & \mathbf{G} \otimes \mathbf{A} & 0 \\
0 & 0 & \mathbf{R} \otimes \mathbf{I}
\end{array}\right],
$$

where

$$
\mathbf{H Y}=\left[\begin{array}{cc}
\sigma_{h y 1}^{2} & \sigma_{h y 12} \\
\sigma_{h y 12} & \sigma_{h y 2}^{2}
\end{array}\right]
$$

is the $($ co)variance $(2 \times 2)$ matrix between traits due to herd-year calving effects;

$$
\mathbf{G}=\left[\begin{array}{cc}
\sigma_{a 1}^{2} & \sigma_{a 12} \\
\sigma_{a 12} & \sigma_{a 2}^{2}
\end{array}\right]
$$

is the covariance $(2 \times 2)$ matrix between traits due to animal additive genetic effects, and

$$
\mathbf{R}=\left[\begin{array}{cc}
\sigma_{\mathrm{e} 1}^{2} & \sigma_{\mathrm{e} 12} \\
\sigma_{\mathrm{e} 12} & \sigma_{\mathrm{e} 2}^{2}
\end{array}\right]
$$

is the residual covariance $(2 \times 2)$ matrix between traits; $\otimes$ is the Kronecker product; $\mathbf{A}$ is the additive relationship matrix; and $\mathbf{I}$ is an identity matrix.

Heritability for each trait was calculated from univariate analysis as

$$
h^{2}=\sigma_{a}^{2} /\left(\sigma_{h y}^{2}+\sigma_{a}^{2}+\sigma_{e}^{2}\right) .
$$

Heritability estimates from threshold model were transformed to an observed scale for comparison purposes, using the Dempster and Lerner (1950) method:

$$
h_{\text {obs }}^{2}=h_{\text {und }}^{2} \times\left(z_{\text {ord }}\right)^{2} / p \times(1-p),
$$

where $h_{o b s}^{2}$ is heritability on an observed scale, $h_{u n d}^{2}$ is heritability on the underlying scale estimated with the threshold model, $z_{\text {ord }}$ is the ordinate height of the normal distribution at the threshold point corresponding to $p$, and $p$ is the prevalence of $\mathrm{SCM}_{150}, \mathrm{SCM}_{200}, \mathrm{SCM}_{250}$, $\mathrm{SCM}_{400,150}, \mathrm{SCM}_{400,200}$, or $\mathrm{SCM}_{400,250}$.

Spearman rank correlations between EBV predicted using the $6 \mathrm{SCM}$ traits and between EBV predicted using 2 statistical approaches (linear vs. threshold model) were calculated using the CORR procedure of SAS (SAS Institute, 2013). Only 69 sires with at least 20 daughters in 5 herds were included in this part of the analysis.

\section{RESULTS}

\section{Descriptive Statistics}

Mean SCC was high in first-lactation heifers during early lactation, and then declined gradually and became 
Table 1. Prevalence (\%) of subclinical mastitis (SCM) in first-lactation heifers from 5 to 30 DIM across Canadian provinces for alternative SCM traits ${ }^{2}$

\begin{tabular}{|c|c|c|c|c|c|c|c|}
\hline \multirow[b]{2}{*}{ Trait } & \multicolumn{6}{|c|}{ Province $^{1}$} & \multirow[b]{2}{*}{ Total } \\
\hline & $\mathrm{AB}$ & $\mathrm{NB}$ & NS & $\mathrm{ON}$ & $\mathrm{PE}$ & $\mathrm{QC}$ & \\
\hline$\overline{\mathrm{SCM}_{150}}$ & 19.0 & 23.3 & 21.8 & 26.8 & 27.1 & 25.8 & 24.3 \\
\hline $\mathrm{SCM}_{200}$ & 14.4 & 19.0 & 17.5 & 20.9 & 21.1 & 19.5 & 18.7 \\
\hline $\mathrm{SCM}_{250}$ & 12.0 & 15.4 & 14.8 & 17.0 & 16.7 & 15.4 & 15.2 \\
\hline $\mathrm{SCM}_{400,150}$ & 15.4 & 17.5 & 17.6 & 22.0 & 21.6 & 20.6 & 19.6 \\
\hline $\mathrm{SCM}_{400,200}$ & 11.9 & 15.1 & 14.8 & 17.9 & 17.6 & 16.6 & 15.9 \\
\hline $\mathrm{SCM}_{400,250}$ & 10.4 & 12.9 & 12.9 & 15.0 & 14.2 & 14.1 & 13.4 \\
\hline
\end{tabular}

stable over the remainder of the first lactation (Figure 1a). In early lactation, mean SCC was high from 5 to 10 DIM and then decreased from 11 to 30 DIM (Figure $1 b)$. Among the first 3 traits $\left(\mathrm{SCM}_{150}, \mathrm{SCM}_{200}\right.$, and $\mathrm{SCM}_{250}$ ), which were defined by single threshold values from 5 to $30 \mathrm{DIM}, \mathrm{SCM}_{150}$ had the highest overall SCM prevalence of $24.3 \%$ followed by $\mathrm{SCM}_{200}(18.7 \%)$, and $\mathrm{SCM}_{250}(15.2 \%)$ (Table 1). As expected, prevalence of SCM decreased with an increasing threshold value of SCC. Likewise, among the other 3 traits $\left(\mathrm{SCM}_{400,150}\right.$, $\mathrm{SCM}_{400,200}$, and $\mathrm{SCM}_{400,250}$ ) that accounted for dilution effect, $\mathrm{SCM}_{400,150}$ had the highest overall prevalence of $19.6 \%$ followed by $\mathrm{SCM}_{400,200}(15.9 \%)$ and $\mathrm{SCM}_{400,250}$ (13.4\%). These traits also had a similar pattern as the first 3 traits $\left(\mathrm{SCM}_{150}, \mathrm{SCM}_{200}\right.$, and $\left.\mathrm{SCM}_{250}\right)$. Across provinces, prevalence of SCM from 5 to 30 DIM ranged from 10.4 to $27.1 \%$ for the 6 SCM traits. Prevalence of $\mathrm{SCM}$ was highest in Ontario (range $=15.0$ to $26.8 \%$ ) and Prince Edward Island (range $=14.2$ to $27.1 \%$ ), but lowest in Alberta (range $=10.4$ to $19.0 \%$ ). In general, overall and across-province prevalence of SCM was high in early lactation but decreased as the threshold used to differentiate affected and not affected heifers increased.

\section{Genetic Parameters of SCM}

Heritability estimates (SE) from the linear model ranged from 0.037 to 0.057 (0.015 to 0.018; Table 2). Among the first 3 traits, highest heritability was estimated for $\mathrm{SCM}_{150}(0.057)$, followed by $\mathrm{SCM}_{200}(0.053)$ and $\mathrm{SCM}_{250}(0.037)$. As heritability is frequency dependent, it decreased with increasing threshold of SCC used to define SCM traits. Likewise, heritability of the latter 3 traits $\left(\mathrm{SCM}_{400,150}, \mathrm{SCM}_{400,200}\right.$, and $\left.\mathrm{SCM}_{400,250}\right)$ that accounted for the dilution effect were in the same range as heritability of the first 3 traits. Heritability also decreased with decreasing average prevalence of $\mathrm{SCM}$ in a trait. Heritability of $\mathrm{SCM}_{400,150}, \mathrm{SCM}_{400,200}$, and $\mathrm{SCM}_{400,250}$ was $0.051,0.048$ and 0.040 , respectively (Table 2).

Heritabilities estimated (SE) from the threshold model (underlying scale) ranged from 0.040 to 0.051 (0.017 to 0.020). These heritabilities estimates were lower compared with the estimates from linear model. However, threshold model estimates were not significantly different from estimates from linear model. Heritability was highest for $\mathrm{SCM}_{200}(0.051)$, followed by $\mathrm{SCM}_{150}(0.046)$ and $\mathrm{SCM}_{250}$ (0.040). Traits $\mathrm{SCM}_{400,150}$ and $\mathrm{SCM}_{400,200}$ had the same heritability estimation of 0.047 , whereas $\mathrm{SCM}_{400,250}$ had a lower estimation of 0.043 . However, pattern of reduction in the heritability estimates from linear model with increase of threshold of SCC used to define SCM traits were not observable here, as heritability estimation from the threshold

Table 2. Heritability ${ }^{1}$ on the underlying scale $\left(h_{u n d}^{2}\right)$ and heritability transformed into an observed scale through the Dempster and Lerner (1950) method $\left(h_{\text {obs- } t}^{2}\right)$ from univariate probit threshold animal model, and heritability on the observed scale $\left(h_{o b s-1}^{2}\right)$ from univariate linear animal model for alternative SCM traits ${ }^{2}$ (SE in parentheses)

\begin{tabular}{lclc}
\hline Trait & $h_{\text {und }}^{2}$ & $h_{\text {obs- } t}^{2}$ & $h_{\text {obs- } 1}^{2}$ \\
\hline $\mathrm{SCM}_{150}$ & $0.046(0.017)$ & 0.024 & $0.057(0.018)$ \\
$\mathrm{SCM}_{200}$ & $0.051(0.018)$ & 0.025 & $0.053(0.017)$ \\
$\mathrm{SCM}_{250}$ & $0.040(0.019)$ & 0.017 & $0.037(0.015)$ \\
$\mathrm{SCM}_{400,150}$ & $0.047(0.018)$ & 0.023 & $0.051(0.017)$ \\
$\mathrm{SCM}_{400,200}$ & $0.047(0.019)$ & 0.021 & $0.048(0.016)$ \\
$\mathrm{SCM}_{400,250}$ & $0.043(0.020)$ & 0.017 & $0.040(0.015)$ \\
\hline
\end{tabular}

${ }^{1}$ Heritability $\left(h^{2}\right)$ for each trait was calculated from univariate analysis as $h^{2}=\sigma_{a}^{2} /\left(\sigma_{\text {hy }}^{2}+\sigma_{\mathrm{a}}^{2}+\sigma_{\mathrm{e}}^{2}\right)$, where $\sigma_{h y}^{2}, \sigma_{a}^{2}$, and $\sigma_{e}^{2}$ are the herd-year of calving, animal additive genetic, and residual variances, respectively. ${ }^{2} \mathrm{SCM}_{150}, \mathrm{SCM}_{200}$, and $\mathrm{SCM}_{250}=$ presence of $\mathrm{SCC}>150,000,200,000$, and 250,000 cells $/ \mathrm{mL}$ at $5 \leq \mathrm{DIM} \leq 30$, respectively. $\mathrm{SCM}_{400,150}$, $\mathrm{SCM}_{400,200}$, and $\mathrm{SCM}_{400.250}=$ presence of $\mathrm{SCC}>400,000$ cells $/ \mathrm{mL}$ at $5 \leq \mathrm{DIM} \leq 10$ and $\mathrm{SCC}>150,000,200,000$, and 250,000 cells $/ \mathrm{mL}$, respectively, at $11 \leq \mathrm{DIM} \leq 30$. 
Table 3. Genetic correlations (above the diagonal; SE in parentheses) and phenotypic correlations (below the diagonal; SE in parentheses) estimated from bivariate linear animal models for alternative SCM traits ${ }^{1}$

\begin{tabular}{|c|c|c|c|c|c|c|}
\hline Trait & $\mathrm{SCM}_{150}$ & $\mathrm{SCM}_{200}$ & $\mathrm{SCM}_{250}$ & $\mathrm{SCM}_{400,150}$ & $\mathrm{SCM}_{400,200}$ & $\mathrm{SCM}_{400,250}$ \\
\hline$\overline{\mathrm{SCM}_{150}}$ & & $\begin{array}{c}0.998 \\
(0.017)\end{array}$ & $\begin{array}{c}0.941 \\
(0.052)\end{array}$ & $\begin{array}{c}0.906 \\
(0.046)\end{array}$ & $\begin{array}{c}0.932 \\
(0.052)\end{array}$ & $\begin{array}{c}0.909 \\
(0.069)\end{array}$ \\
\hline $\mathrm{SCM}_{200}$ & $\begin{array}{c}0.848 \\
(0.003)\end{array}$ & & $\begin{array}{c}0.991 \\
(0.019)\end{array}$ & $\begin{array}{c}0.990 \\
(0.028)\end{array}$ & $\begin{array}{c}0.988 \\
(0.016)\end{array}$ & $\begin{array}{c}0.973 \\
(0.031)\end{array}$ \\
\hline $\mathrm{SCM}_{250}$ & $\begin{array}{c}0.748 \\
(0.005)\end{array}$ & $\begin{array}{c}0.882 \\
(0.002)\end{array}$ & & $\begin{array}{c}0.949 \\
(0.054)\end{array}$ & $\begin{array}{c}0.993 \\
(0.025)\end{array}$ & $\begin{array}{c}0.976 \\
(0.020)\end{array}$ \\
\hline $\mathrm{SCM}_{400,150}$ & $\begin{array}{c}0.871 \\
(0.003)\end{array}$ & $\begin{array}{c}0.787 \\
(0.004)\end{array}$ & $\begin{array}{c}0.731 \\
(0.005)\end{array}$ & & $\begin{array}{c}0.996 \\
(0.015)\end{array}$ & $\begin{array}{c}0.944 \\
(0.043)\end{array}$ \\
\hline $\mathrm{SCM}_{400,200}$ & $\begin{array}{c}0.767 \\
(0.005)\end{array}$ & $\begin{array}{c}0.905 \\
(0.002)\end{array}$ & $\begin{array}{c}0.839 \\
(0.003)\end{array}$ & $\begin{array}{c}0.8792 \\
(0.003)\end{array}$ & & $\begin{array}{c}0.995 \\
(0.013)\end{array}$ \\
\hline $\mathrm{SCM}_{400,250}$ & $\begin{array}{c}0.695 \\
(0.006)\end{array}$ & $\begin{array}{c}0.820 \\
(0.004)\end{array}$ & $\begin{array}{c}0.929 \\
(0.002)\end{array}$ & $\begin{array}{c}0.797 \\
(0.004)\end{array}$ & $\begin{array}{c}0.907 \\
(0.002)\end{array}$ & \\
\hline
\end{tabular}

${ }^{1} \mathrm{SCM}_{150}, \mathrm{SCM}_{200}$ and $\mathrm{SCM}_{250}=$ presence of $\mathrm{SCC}>150,000,200,000$ and 250,000 cells $/ \mathrm{mL}$ at $5 \leq \mathrm{DIM} \leq 30$, respectively. $\mathrm{SCM}_{400,150}, \mathrm{SCM}_{400,200}$ and $\mathrm{SCM}_{400,250}=$ presence of $\mathrm{SCC}>400,000$ cells $/ \mathrm{mL}$ at $5 \leq \mathrm{DIM} \leq 10$ and $\mathrm{SCC}>150,000,200,000$ and 250,000 cells/mL, respectively, at $11 \leq \mathrm{DIM} \leq 30$.

model does not depend on the frequency. To compare heritability estimations from linear and threshold models, threshold model estimations were converted to an observed scale (Dempster and Lerner, 1950). Converted heritabilities were lower than from linear models and ranged from 0.017 to 0.025 for the 6 studied traits.

Genetic correlations (SE) estimated from linear animal models among the 6 traits were very strong and ranged from 0.906 to 0.998 (0.013 to 0.069; Table 3). Among the first 3 traits $\left(\mathrm{SCM}_{150}, \mathrm{SCM}_{200}\right.$, and $\left.\mathrm{SCM}_{250}\right)$, genetic correlations were stronger when thresholds of these traits were closer to each other. Likewise, the latter 3 traits $\left(\mathrm{SCM}_{400,150}, \mathrm{SCM}_{400,200}\right.$, and $\left.\mathrm{SCM}_{400,250}\right)$ had a similar pattern. With respect to genetic correlations between the first and last 3 traits, the strongest value was between $\mathrm{SCM}_{250}$ and $\mathrm{SCM}_{400,200}$ (0.993), whereas the lowest estimation was between $\mathrm{SCM}_{150}$ and $\mathrm{SCM}_{400,150}(0.906)$.

Moderate to strong phenotypic correlations were estimated among all 6 traits (Table 3). Similar to the pattern genetic of correlations, phenotypic correlations were stronger among traits with a threshold close to each other. The strongest correlation (0.929) was between $\mathrm{SCM}_{250}$ and $\mathrm{SCM}_{400,250}$; the lowest correlation of 0.695 was estimated between $\mathrm{SCM}_{150}$ and $\mathrm{SCM}_{400,250}$. Estimated residual correlations were moderate to high (0.715 to 0.926$)$ and tended to be similar to genetic correlations in direction (Table 4 ).

\section{Prediction of Breeding Values}

Moderate to high Spearman rank correlations were estimated among EBV of the 6 analyzed traits predicted from linear and threshold models (Table 5). With respect to EBV predicted from linear models, there was a similar high Spearman rank correlation of 0.95 between EBV of $\mathrm{SCM}_{200}$ and $\mathrm{SCM}_{250}$ as well as $\mathrm{SCM}_{400,200}$ and $\mathrm{SCM}_{400,250}$, respectively. The lowest correlation (0.75) was estimated between EBV of $\mathrm{SCM}_{150}$ and $\mathrm{SCM}_{400,250}$. Rank correlations within EBV for the same trait predicted from threshold models ranged from 0.74 to 0.95 . Furthermore, rank correlation between EBV predicted

Table 4. Residual correlations (above the diagonal; $\mathrm{SE}$ in parentheses) estimated from bivariate linear animal models for alternative SCM traits ${ }^{1}$

\begin{tabular}{|c|c|c|c|c|c|}
\hline Trait & $\mathrm{SCM}_{200}$ & $\mathrm{SCM}_{250}$ & $\mathrm{SCM}_{400,150}$ & $\mathrm{SCM}_{400,200}$ & $\mathrm{SCM}_{400,250}$ \\
\hline $\mathrm{SCM}_{150}$ & $\begin{array}{c}0.836 \\
(0.004)\end{array}$ & $\begin{array}{c}0.7330 \\
(0.007)\end{array}$ & $\begin{array}{c}0.867 \\
(0.004)\end{array}$ & $\begin{array}{c}0.7530 \\
(0.006)\end{array}$ & $\begin{array}{c}0.680 \\
(0.008)\end{array}$ \\
\hline $\mathrm{SCM}_{200}$ & & $\begin{array}{c}0.876 \\
(0.003)\end{array}$ & $\begin{array}{c}0.772 \\
(0.006)\end{array}$ & $\begin{array}{c}0.899 \\
(0.003)\end{array}$ & $\begin{array}{c}0.810 \\
(0.005)\end{array}$ \\
\hline $\mathrm{SCM}_{250}$ & & & $\begin{array}{c}0.715 \\
(0.007)\end{array}$ & $\begin{array}{c}0.826 \\
(0.005)\end{array}$ & $\begin{array}{c}0.926 \\
(0.002)\end{array}$ \\
\hline $\mathrm{SCM}_{400,150}$ & & & & $\begin{array}{c}0.871 \\
(0.003)\end{array}$ & $\begin{array}{c}0.785 \\
(0.006)\end{array}$ \\
\hline $\mathrm{SCM}_{400,200}$ & & & & & $\begin{array}{c}0.900 \\
(0.003)\end{array}$ \\
\hline
\end{tabular}

${ }^{1} \mathrm{SCM}_{150}, \mathrm{SCM}_{200}$, and $\mathrm{SCM}_{250}=$ presence of $\mathrm{SCC}>150,000,200,000$, and 250,000 cells $/ \mathrm{mL}$ at $5 \leq \mathrm{DIM}<30$, respectively. $\mathrm{SCM}_{400,150}, \mathrm{SCM}_{400,200}$, and $\mathrm{SCM}_{400,250}=$ presence of $\mathrm{SCC}>400,000$ cells $/ \mathrm{mL}$ at $5 \leq \mathrm{DIM} \leq 10$ and $\mathrm{SCC}>150,000,200,000$, and 250,000 cells $/ \mathrm{mL}$, respectively, at $11 \leq \mathrm{DIM} \leq 30$. 
Table 5. Rank correlations between EBV predicted using linear (above the diagonal) and threshold animal models (below the diagonal) for alternative SCM traits $^{1}$ for 69 sires with at least 20 daughters in 5 herds

\begin{tabular}{lcccccc}
\hline Trait & $\mathrm{SCM}_{150}$ & $\mathrm{SCM}_{200}$ & $\mathrm{SCM}_{250}$ & $\mathrm{SCM}_{400,150}$ & $\mathrm{SCM}_{400,200}$ & $\mathrm{SCM}_{400,250}$ \\
\hline $\mathrm{SCM}_{150}$ & 0.92 & 0.92 & 0.86 & 0.86 & 0.84 & 0.75 \\
$\mathrm{SCM}_{200}$ & 0.86 & 0.94 & 0.95 & 0.85 & 0.92 & 0.85 \\
$\mathrm{SCM}_{250}$ & 0.88 & 0.85 & 0.86 & 0.84 & 0.90 & 0.91 \\
$\mathrm{SCM}_{400,150}$ & 0.84 & 0.92 & 0.92 & 0.94 & 0.94 & 0.90 \\
$\mathrm{SCM}_{400,200}$ & 0.74 & 0.83 & 0.91 & 0.90 & 0.95 & \\
$\mathrm{SCM}_{400,250}$ & &
\end{tabular}

${ }^{1} \mathrm{SCM}_{150}, \mathrm{SCM}_{200}$, and $\mathrm{SCM}_{250}=$ presence of $\mathrm{SCC}>150,000,200,000$, and 250,000 cells $/ \mathrm{mL}$ at $5 \leq \mathrm{DIM} \leq 30$, respectively. $\mathrm{SCM}_{400,150}, \mathrm{SCM}_{400,200}$, and $\mathrm{SCM}_{400,250}=$ presence of $\mathrm{SCC}>400,000$ cells $/ \mathrm{mL}$ at $5 \leq \mathrm{DIM} \leq 10$ and $\mathrm{SCC}>150,000,200,000$, and 250,000 cells $/ \mathrm{mL}$, respectively, at $11 \leq \mathrm{DIM} \leq 30$.

from linear and threshold models ranged from 0.98 to 0.99 .

Despite low heritability, we found significant variations in sires' EBV (Table 6). Estimated breeding values were reversed in sign to relate higher EBV to sires with more healthy daughters. Mean percentage of daughters with SCM ranged from 12.5 to $18.4 \%$ for the analyzed 6 traits. Based on the linear model estimation, the percentage of daughters with SCM ranged from 5.6 to $13.6 \%$ and from 19.5 to $33.3 \%$ for the best (10\% decile) and worst (90\% decile) sires, respectively (within 5 to 30 DIM). Similarly, percentage of daughters with SCM in early lactation estimated based on a threshold model varied from 5.6 to $14.9 \%$ and from 18.2 to $33.3 \%$ for the best and worst sires, respectively. These sires were the best $10 \%$ and worst $10 \%$ of the 69 sires with minimum 20 daughters in at least 5 herds. Although heritability of SCM was low, we noted a large exploitable variation in percentage of healthy daughters per sire's EBV within 5 to 30 DIM (Figure 2).

\section{DISCUSSION}

Mean SCC was high in early lactation and then gradually decreased and remained stable at approximately 35
DIM (Figures 1a and 1b). A similar pattern of SCC was observed by Koeck et al. (2012a) for first-lactation heifers with and without clinical mastitis (5 to 305 DIM). However, SCC of cows with clinical mastitis was higher throughout lactation. In the current study, mean SCC of diseased cows was higher than SCC of healthy cows from 5 to 30 DIM for the analyzed 6 traits. Likewise, Hagnestam-Nielsen et al. (2009) reported a similar trend for geometric mean SCC for primiparous cows with SCM and without SCM. Those authors defined SCM using a threshold of 175,000 and 50,000 cells $/ \mathrm{mL}$ at 1 wk and 2 to 44 wk of lactation, respectively. Distribution of SCC throughout lactation is affected by several factors, including IMI status, herd, sampling time, quarter location, stage of lactation, parity, season, milk production, and cow itself (Harmon, 1994). Elevated SCC in early lactation is mainly due to IMI (Harmon, 1994; Laevens et al., 1997; Barkema et al., 1999). Intramammary infection at calving, particularly thta caused by major pathogens (Staphylococcus aureus, Streptococcus agalactiae, Streptococcus dysgalactiae, Streptococcus uberis, and Escherichia coli), resulted in more elevated SCC compared with IMI caused by minor pathogens and culture-negative quarter milk samples (Barkema et al., 1999). Intramammary infection often occurs ear-

Table 6. Percentage of daughters with subclinical mastitis from all (average), the best (10\% decile), and the worst $(90 \%$ decile) sires [with at least 20 daughters in $>5$ herds $(n=69)$ ] according to their estimated breeding value for resistance to subclinical mastitis predicted with univariate linear and probit threshold models for alternative SCM traits ${ }^{1}$ within 5 to 30 DIM

\begin{tabular}{lcccccc}
\hline & & \multicolumn{2}{c}{ Linear model } & & \multicolumn{2}{c}{ Threshold model } \\
\cline { 3 - 4 } \cline { 6 - 6 } Trait & Average & \multirow{2}{*}{$10 \%$ decile } & $90 \%$ decile & & \multirow{2}{*}{$10 \%$ decile } & $90 \%$ decile \\
\hline $\mathrm{SCM}_{150}$ & 17.9 & 13.6 & 33.3 & & 14.9 & 33.3 \\
$\mathrm{SCM}_{200}$ & 14.2 & 10.1 & 28.5 & & 11.0 & 27.5 \\
$\mathrm{SCM}_{250}$ & 18.4 & 5.7 & 22.4 & & 7.2 & 20.9 \\
$\mathrm{SCM}_{400,150}$ & 18.4 & 10.3 & 28.9 & & 11.2 & 28.7 \\
$\mathrm{SCM}_{400,200}$ & 14.9 & 6.6 & 23.2 & & 7.6 & 23.2 \\
$\mathrm{SCM}_{400,250}$ & 12.5 & 5.6 & 19.5 & & 5.6 & 18.2 \\
\hline
\end{tabular}

${ }^{1} \mathrm{SCM}_{150}, \mathrm{SCM}_{200}$, and $\mathrm{SCM}_{250}=$ presence of $\mathrm{SCC}>150,000,200,000$, and 250,000 cells $/ \mathrm{mL}$ at $5 \leq \mathrm{DIM} \leq 30$, respectively. $\mathrm{SCM}_{400,150}, \mathrm{SCM}_{400,200}$, and $\mathrm{SCM}_{400,250}=$ presence of $\mathrm{SCC}>400,000$ cells $/ \mathrm{mL}$ at $5 \leq \mathrm{DIM} \leq 10$ and $\mathrm{SCC}>150,000,200,000$, and 250,000 cells $/ \mathrm{mL}$, respectively, at $11 \leq \mathrm{DIM} \leq 30$. 
(a)

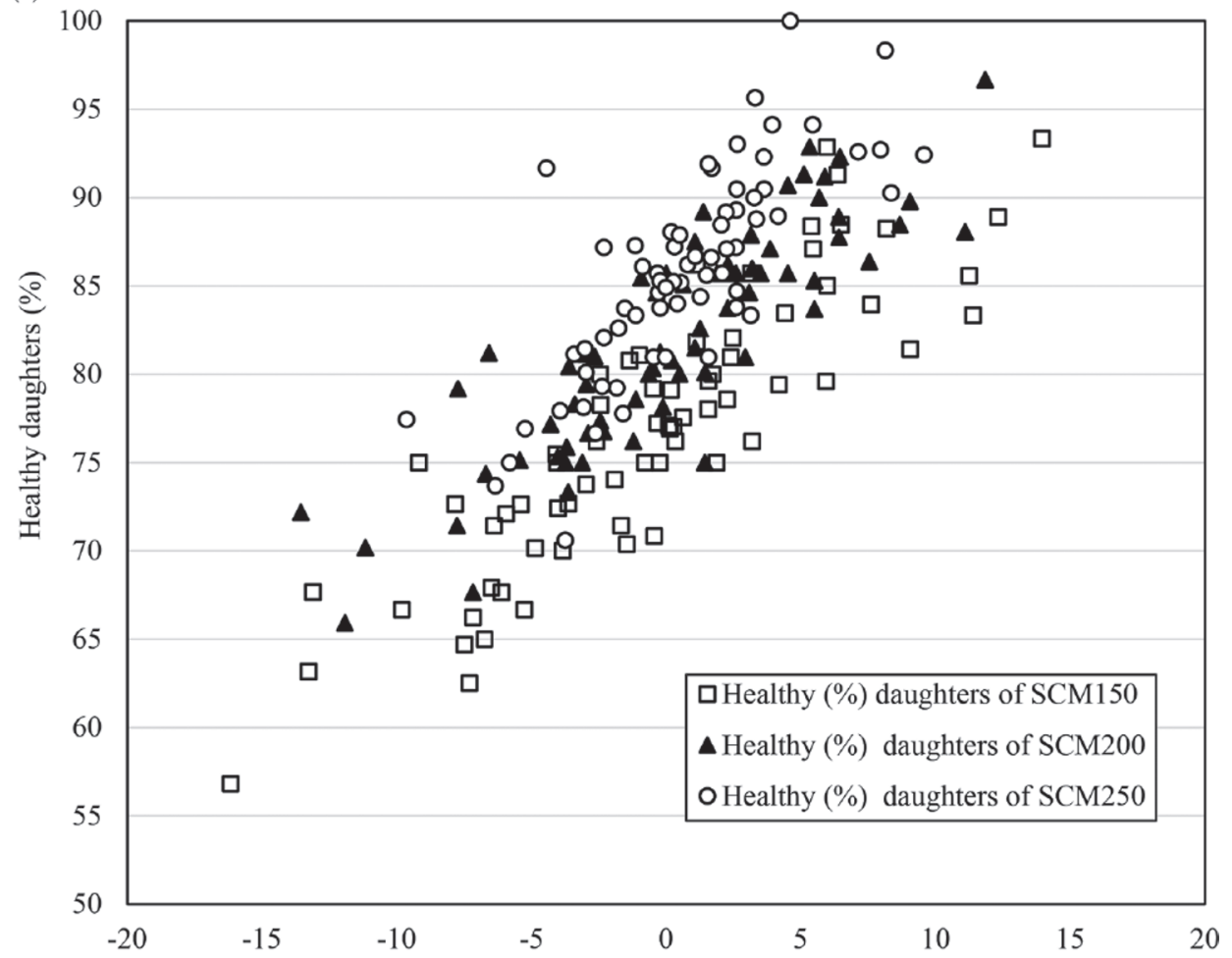

(b)

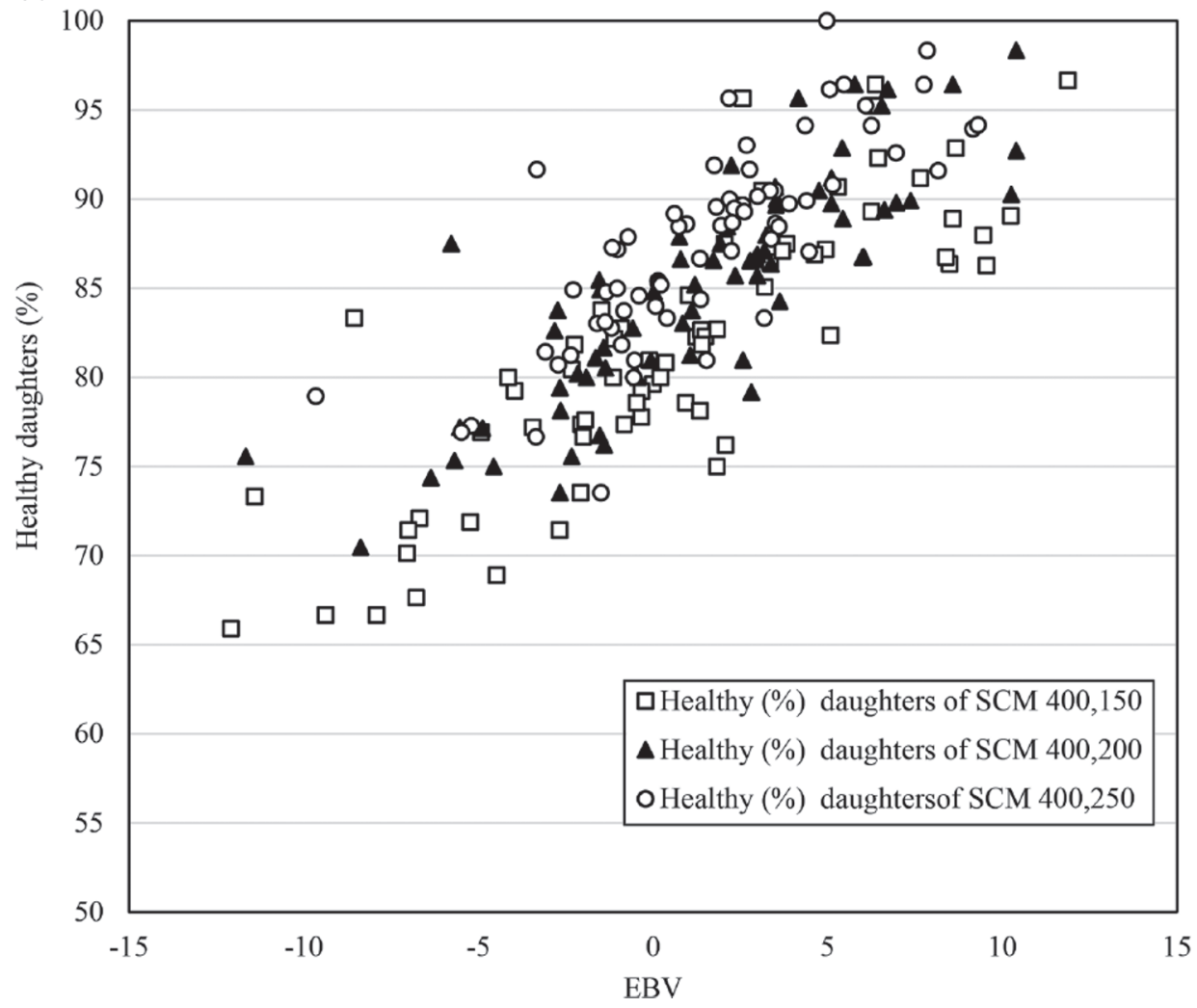

Figure 2. Percentage of healthy daughters according to the EBV estimated using linear model of subclinical mastitis resistance of sires (within 5 to $30 \mathrm{DIM}$ ) with at least 20 daughters in $>5$ herds $(\mathrm{n}=69)$ for (a) $\mathrm{SCM}_{150}, \mathrm{SCM}_{200}$, and $\mathrm{SCM}_{250}=$ presence of SCC $>150,000,200,000$, and 250,000 cells $/ \mathrm{mL}$ at $5 \leq \mathrm{DIM} \leq 30$, respectively, and (b) $\mathrm{SCM}_{400,150}, \mathrm{SCM}_{400,200}$, and $\mathrm{SCM}_{400,250}=$ presence of SCC $>400,000$ cells $/ \mathrm{mL}$ at 5 $\leq \mathrm{DIM} \leq 10$ and $\mathrm{SCC}>150,000,200,000$ and 250,000 cells/mL, respectively, at $11 \leq \mathrm{DIM} \leq 30$. 
lier in life (Trinidad et al., 1990) and persists for an extended interval if unresolved, resulting in elevated SCC in early lactation. Additionally, negative energy balance status in early lactation (Nyman et al., 2008) increases susceptibility to new IMI, due to impaired immune functions (Nyman et al., 2008; Wathes et al., 2009; Esposito et al., 2014).

The dilution effect of milk also has a role in increasing SCC in early lactation if no IMI is present. At the onset of lactation, milk production is low, which results in high SCC in milk (Schepers et al., 1997). Therefore, in the present study, traits $\mathrm{SCM}_{400,150}, \mathrm{SCM}_{400,200}$, and $\mathrm{SCM}_{400,250}$ were defined to account for the dilution effect (based on Figure 1b) by having a higher threshold value of 400,000 cells $/ \mathrm{mL}$ within 5 to 10 DIM and slightly lower values from 11 to 30 DIM $(150,000,200,000$, and 250,000 cells $/ \mathrm{mL}$ ). Somatic cell count of quarter milk is elevated immediately postpartum, regardless of infection status, but SCC of quarters without IMI rapidly declines, likely as a result of the dilution effect (Harmon, 1994; Barkema et al., 1999). Emanuelson and Funke (1991) estimated a dilution effect of $11 \%$ when estimated conditionally on mastitis prevalence. Reports on the interval after calving reported a physiological elevated SCC in noninfected quarters, which differed from 3 to 35 DIM (Reichmuth, 1975; Sheldrake et al., 1983); however, this elevation of SCC was lower compared with SCC from infected quarters (Harmon, 1994; Barkema et al., 1999). However, the presence of a dilution effect was not conclusive across studies. In a recent study by Boland and More (2013), there was no evidence of a dilution effect in Irish Dairy cattle. Regardless, based on Figure $1 \mathrm{~b}$ traits, $\mathrm{SCM}_{400,150}$, $\mathrm{SCM}_{400,200}$, and $\mathrm{SCM}_{400,250}$ were defined to account for a potential dilution effect in the present study. Therefore, they had high threshold of SCC 400,000 cells/mL from 5 to 10 DIM and lower thresholds (150,000, 200,000, and 250,000 cells $/ \mathrm{mL}$ ) from 11 to 30 DIM; a similar approach was taken in a study by Koeck et al. (2012b).

Several studies have reported a wide range of prevalence for SCM. Due to inconsistencies in defining SCM and the interval under consideration, it is difficult to compare prevalence among studies (Ruegg, 2017). However, Jaeger et al. (2017) recently reported that a SCC threshold of 150,000 cells/mL was an optimal threshold to identify IMI with all possible pathogens, with sensitivity of $90.3 \%$ and specificity of $71.8 \%$. Moreover, a quarter milk SCC is preferred over a composite milk SCC to identify SCM, as increases in quarter SCC gets diluted in the latter (Barkema et al., 1999). Besides, several studies also reported that SCC patterns provided additional information compared with mean lactation SCC for genetic evaluation of mastitis resistance (De Haas et al., 2003; Koeck et al., 2012b).
Estimated overall and across-provinces prevalence of early-lactation SCM in heifers was comparable to other studies, despite variations among studies. A recent review reported a high quarter-level early postpartum SCM prevalence of 12 to 57\% (De Vliegher et al., 2012). Similar to the lactation stage (5 to 30 DIM) analyzed in the present study, Naqvi et al. (2018) reported SCM prevalence of 13,15 , and $20 \%$ in low (SCC $<150,000$ cells $/ \mathrm{mL}$ ), medium ( $\mathrm{SCC}=150,000$ to 300,00 cells $/$ $\mathrm{mL}$ ), and high ( $\mathrm{SCC}>300,00$ cells $/ \mathrm{mL}$ ) bulk milk SCC categories within the first 30 DIM. In agreement with the presented study, those authors also reported Alberta had the lowest prevalence of SCM; Naqvi et al. (2018) also defined SCM using a threshold of 200,000 cells/mL. In comparison to the present study, Santman-Berends and Sampimon (2011) reported that $26 \%$ of cows per herd had SCM from 4 to 100 DIM based on a threshold of 150,000 cells/mL. Additionally, in the present study, prevalence of SCM decreased as the threshold used to differentiate affected and not affected heifers increased. De Vliegher et al. (2001) also reported a similar pattern of reducing prevalence $(65,16,13$, and $6 \%$, respectively) with increasing threshold in early lactation (5 to 14 DIM), with thresholds ranging from 150,000 to $1,000,000$ cells/mL. In support of this view, Svendsen and Heringstad, (2006) estimated prevalences of 45.5, 25,17 , and $12 \%$ for SCM with thresholds of 50,000, 100,000, 150,000, and 200,000 cells/mL, respectively, from 30 to 270 DIM in first-lactation heifers.

In many studies, genetic evaluation of SCC was based on lactational average SCC or SCS. Moreover, comparisons among estimated heritabilities of SCM are difficult, as heritability varies with the definition of SCM and on the interval considered. However, estimated heritabilities (0.037 to 0.057) from a linear model in the present study were in line with other studies. In general, heritability of SCM using a linear model ranged from 0.03 to 0.17 (Koivula et al., 2004; Svendsen and Heringstad, 2006; De Haas et al., 2008; Urioste et al., 2012). Most studies have focused on the entire first lactation, whereas very few have explored only early lactation (Koivula et al., 2004). A heritability of 0.05 was reported by Koeck et al. (2012b) using a linear model for a trait defined as cows with at least 1 SCC test-day above 500,000, 300,000, and 200,000 cells/mL within 5 to 10,11 to 30 , and 31 to 305 DIM, respectively, considered as affected (1) or otherwise as healthy (0). Those authors defined SCM with higher thresholds for 5 to 10 DIM and 11 to 30 DIM than used in the present current study and their analysis was done for the entire lactation (until 305 DIM). In addition, the same authors reported a low heritability of 0.03 for high SCC, defined as at least 1 SCC test-day $>500,000$ cells $/ \mathrm{mL}$ from 5 to 305 DIM. Comparable 
to the present study, Svendsen and Heringstad (2006) reported lower heritabilities with an increasing threshold used to define SCM. Estimated heritabilities were $0.086,0.078,0.059$, and 0.045 for SCM with threshold ranges of 50,000 to 200,000 cells $/ \mathrm{mL}$, respectively, in the first lactation from 30 to 270 DIM using a linear sire model. This may be due to decreased frequency of affected cows and frequency dependency of linear models (Gianola, 1982); a similar pattern was reported by Koeck et al. (2012b).

De Haas et al. (2008) reported a low heritability (0.03 to 0.04) for SCM for primiparous cows over the course of first lactation using a linear model. Those authors defined SCM as a transition from 2 consecutive SCC recordings below and above thresholds of 150,000 cells/ $\mathrm{mL}$. De Haas et al. (2008) also reported a heritability of 0.06 for trait suspicion of IMI, defined as absence or presence of test-day SCC $>150,000$ cells $/ \mathrm{mL}$. This was similar to the present study for $\mathrm{SCM}_{150}$ with a linear model (0.057). Koivula et al. (2004) reported heritabilities of 0.045 and 0.094 from 5 to 20 and 31 to 60 DIM, respectively, for $\log _{\mathrm{e}} \mathrm{SCC}$ in first lactation for Holsteins using a linear model. Likewise, Koivula et al. (2004) stated that the low heritability during early lactation was partly due to larger environmental variation. In contrast to other reports, Urioste et al. (2012) estimated a higher heritability of 0.17 for first lactation, which may have been due to SCM defined as number of periods from DIM $>45$ with a SCC $>150,000$ cells $/ \mathrm{mL}$ and without treatment for clinical mastitis.

Threshold models are theoretically more appropriate for analysis of binary traits, as they assume existence of an underlying normally distributed variable (Gianola and Foulley, 1983). Moreover, threshold models provide a better comparison between traits and studies with different prevalence, as it is not as frequency-dependent as a linear model (Gianola, 1982). However, computational demand may pose a problem for routine genetic evaluation based on a large data set using a threshold model. Application of linear models to binomial traits is a common approach in routine genetic evaluation, as it is less computationally demanding. Furthermore, we found no difference in sire ranking using both models when progeny group size was large (Heringstad et al., 2003; Negussie et al., 2008). In the present study, heritabilities estimated from threshold models ranged from 0.040 to 0.051 ; however, very few studies have been published on estimates of heritability for SCM, treating it as binary trait and using a threshold probability model for genetic analysis. Haugaard et al. (2013) reported heritabilities (underlying scale) of 0.04 (0.01) to $0.14(0.03)$ for the pathogen-specific SCM using a threshold sire model. However, those authors defined the SCM based on test-day SCC records (threshold of 100,000 cells $/ \mathrm{mL}$ ) and bacteriological results of milk samples. Regardless, several studies reported heritability estimates for $\mathrm{CM}$ that ranged from 0.05 to 0.126 using threshold models (Kadarmideen et al., 2000; Heringstad et al., 2003; Hinrichs et al., 2005). In general, heritability estimation from threshold models on a probability scale is higher than estimation from a linear model (Heringstad et al., 1997; Kadarmideen et al., 2000); however, in our study, it was lower but not significantly different from linear model estimates. For comparison purposes of heritabilities estimated from linear and threshold models, threshold model estimations in the present study were converted to an observed scale (Dempster and Lerner, 1950). After transformation, heritability estimations from the threshold model were lower than the linear model and ranged from 0.017 to 0.025 for the 6 studied traits. Because a similar model was used for both statistical approaches with the same data set, lower heritability estimation from the threshold model on underlying and observed scale might be due to the small sample size and the nature of the data used in the current study; therefore, future studies with large data sets are required.

High genetic correlations among the 6 traits studied demonstrated that these traits were genetically similar. Similarly, Svendsen and Heringstad (2006) also reported high genetic correlations (range $=0.89$ to 0.92 ) between the most different SCM traits defined with thresholds of 50,000 and 200,000 cells $/ \mathrm{mL}$. Those authors also reported a moderate residual correlation (range $=0.31$ to 0.37 ) between SCM traits.

Moderate to high Spearman rank correlations were estimated among EBV of 6 traits predicted from linear and threshold models; therefore, we inferred a likely reranking of sires based on the chosen trait would occur. In contrast, very high rank correlations between EBV predicted for the same trait from linear versus threshold models suggested sire rankings may not differ between threshold versus linear models. Hence, linear models are robust and could be used in genetic evaluation of binary traits. A paucity of reports exists comparing threshold and linear models for SCM within 30 DIM. Similar to the present study, Heringstad et al. (2003) also estimated a high rank correlation $(>0.99)$ between sire evaluation based on threshold and linear models for clinical mastitis. This was in agreement with other studies exploring various conditions, including lameness (Malchiodi et al., 2017) and dystocia (Renand et al., 1990); however, it was stated that limited information per sire could affect sire rankings using threshold versus linear models (Negussie et al., 2008). Importantly, the present study demonstrated that, despite low heritabil- 
ity, there was significant variation in sires' EBV. Therefore, this represented an opportunity to use breeding to improve genetic resistance to SCM in early lactation.

\section{CONCLUSIONS}

Despite relatively low heritability, we noted significant exploitable genetic variability among sires for SCM of heifers early in their first lactation. Hence, opportunity exists for improvement of heifer mastitis through long-term genetic selection. Moreover, high genetic correlations among analyzed 6 traits $\left(\mathrm{SCM}_{150}\right.$, $\mathrm{SCM}_{200}, \mathrm{SCM}_{250}, \mathrm{SCM}_{400,150}, \mathrm{SCM}_{400,200}$, and $\left.\mathrm{SCM}_{400,250}\right)$ indicated that these traits were genetically similar, irrespective of different thresholds. However, sire rankings may differ between traits used to define SCM; therefore, selection of traits to define SCM should be done with caution. Hence, in future studies, estimating sensitivity and specificity will be required to find the best threshold of SCC to define SCM. Regardless, estimated very high Spearman rank correlations between EBV predicted from both linear and threshold models indicated there would be no difference in sire rankings when using threshold versus linear models. Hence, a linear model could be used for routine genetic evaluation of SCM instead of threshold model in the dairy industry, as they are less computationally demanding and robust.

\section{ACKNOWLEDGMENTS}

Dairy producers participating in this project are gratefully acknowledged. This research was supported by the NSERC Industrial Research Chair in Infectious Diseases of Dairy Cattle, funded by Canada's Natural Sciences and Engineering Research Council (NSERC), Industrial Research Chair Program (Ottawa, ON, Canada), with industry contributions from Alberta Milk (Edmonton, AB, Canada), the Dairy Farmers of Canada (Ottawa, ON, Canada), Westgen Endowment Fund (Milner, BC, Canada), the BC Dairy Association (Burnaby, BC, Canada), Canadian Dairy Network (Guelph, ON, Canada), CanWest DHI (Guelph, ON, Canada), and Dairy Farmers of Manitoba (Winnipeg, MB, Canada).

\section{REFERENCES}

Alam, M., C. I. Cho, T. J. Choi, B. Park, J. G. Choi, Y. H. Choy, S. S. Lee, and K. H. Cho. 2015. Estimation of genetic parameters for somatic cell scores of Holsteins using multi-trait lactation models in Korea. Asian-Australas. J. Anim. Sci. 28:303-310.

Barkema, H. W., H. A. Deluyker, Y. H. Schukken, and T. J. G. M. Lam. 1999. Quarter-milk somatic cell count at calving and at the first six milkings after calving. Prev. Vet. Med. 38:1-9.
Boland, F., and S. More. 2013. Investigating a dilution effect between somatic cell count and milk yield and estimating milk production losses in Irish dairy cattle. J. Dairy Sci. 96:1477-1484.

De Haas, Y., H. W. Barkema, Y. H. Schukken, and R. F. Veerkamp. 2003. Genetic associations for pathogen-specific clinical mastitis and patterns of peaks in somatic cell count. Anim. Sci. 77:187-195.

De Haas, Y., W. Ouweltjes, J. Ten Napel, J. J. Windig, and G. De Jong. 2008. Alternative somatic cell count traits as mastitis indicators for genetic selection. J. Dairy Sci. 91:2501-2511.

De Vliegher, S., H. W. Barkema, H. Stryhn, G. Opsomer, and A. De Kruif. 2004. Impact of early lactation somatic cell count in heifers on somatic cell counts over the first lactation. J. Dairy Sci. $87: 3672-3682$.

De Vliegher, S., H. W. Barkema, H. Stryhn, G. Opsomer, and A. De Kruif. 2005. Impact of early lactation somatic cell count in heifers on milk yield over the first lactation. J. Dairy Sci. 88:938-947.

De Vliegher, S., L. K. Fox, S. Piepers, S. McDougall, and H. W. Barkema. 2012. Invited review: Mastitis in dairy heifers: Nature of the disease, potential impact, prevention, and control. J. Dairy Sci. 95:1025-1040.

De Vliegher, S., H. Laevens, G. Opsomer, E. De Muêlenaere, and A. De Kruif. 2001. Somatic cell counts in dairy heifers during early lactation. Vlaams Diergeneeskd. Tijdschr. 70:212-215.

Dempster, E. R., and I. M. Lerner. 1950. Heritability of threshold characters. Genetics 35:212-236.

Emanuelson, U., and H. Funke. 1991. Effect of milk yield on relationship between bulk milk somatic cell count and prevalence of mastitis. J. Dairy Sci. 74:2479-2483.

Esposito, G., P. C. Irons, E. C. Webb, and A. Chapwanya. 2014. Interactions between negative energy balance, metabolic diseases, uterine health and immune response in transition dairy cows. Anim. Reprod. Sci. 144:60-71.

Gianneechini, R., C. Concha, R. Rivero, I. Delucci, and J. Moreno López. 2002. Occurrence of clinical and sub-clinical mastitis in dairy herds in the West Littoral region in Uruguay. Acta Vet. Scand. 43:221-230.

Gianola, D. 1982. Theory and analysis of threshold characters. J. Anim. Sci. 54:1079-1096.

Gianola, D., and J. L. Foulley. 1983. Sire evaluation for ordered categorical data with a threshold model. Genet. Sel. Evol. 15:201-224.

Gilmour, A. R., B. J. Gogel, B. R. Cullis, and R. Thompson. 2009. ASReml User Guide Release 3.0. VSN International Ltd., Hemel Hempstead, UK.

Hagger, C., and A. Hofer. 1990. Genetic analyses of calving traits in the Swiss Black and White, Braunvieh and Simmental breeds by REML and MAPP procedures. Livest. Prod. Sci. 24:93-107.

Hagnestam-Nielsen, C., U. Emanuelson, B. Berglund, and E. Strandberg. 2009. Relationship between somatic cell count and milk yield in different stages of lactation. J. Dairy Sci. 92:3124-3133.

Halasa, T., K. Huijps, and H. Hogeveen. 2007. Economic effects of bovine mastitis and mastitis management: A review. Vet. Q. $29: 18-31$.

Halasa, T., M. Nielen, A. P. W. De Roos, R. Van Hoorne, G. De Jong, T. J. G. M. Lam, T. Van Werven, and H. Hogeveen. 2009. Production loss due to new subclinical mastitis in Dutch dairy cows estimated with a test-day model. J. Dairy Sci. 92:599-606.

Harmon, R. J. 1994. Physiology of mastitis and factors affecting somatic cell counts. J. Dairy Sci. 77:2103-2112.

Haugaard, K., B. Heringstad, and A. C. Whist. 2013. Genetic associations between somatic cell score and pathogen-specific subclinical mastitis in Norwegian Red cows. J. Anim. Breed. Genet. 130:98-105.

Heringstad, B., A. Karlsen, and G. Klemetsdal. 1997. Preliminary results from a genetic analysis of clinical mastitis data. Interbull Bull. 15:45-49.

Heringstad, B., G. Klemetsdal, and J. Ruan. 2000. Selection for mastitis resistance in dairy cattle: a review with focus on the situation in the Nordic countries. Livest. Prod. Sci. 64:95-106.

Heringstad, B., R. Rekaya, D. Gianola, G. Klemetsdal, and K. A. Weigel. 2003. Genetic change for clinical mastitis in Norwegian cattle: A threshold model analysis. J. Dairy Sci. 86:369-375. 
Hinrichs, D., E. Stamer, W. Junge, and E. Kalm. 2005. Genetic analyses of mastitis data using animal threshold models and genetic correlation with production traits. J. Dairy Sci. 88:2260-2268.

Hortet, P., F. Beaudeau, H. Seegers, and C. Fourichon. 1999. Reduction in milk yield associated with somatic cell counts up to 600000 cells/mL in French Holstein cows without clinical mastitis. Livest. Prod. Sci. 61:33-42.

Huijps, K., T. J. Lam, and H. Hogeveen. 2008. Costs of mastitis: Facts and perception. J. Dairy Res. 75:113-120.

Jaeger, S., F. Virchow, P. Torgerson, M. Bischoff, B. Biner, S. Hartnack, and S. Rüegg. 2017. Test characteristics of milk amyloid A ELISA, somatic cell count, and bacteriological culture for detection of intramammary pathogens that cause subclinical mastitis. J. Dairy Sci. 100:7419-7426.

Jamrozik, J., A. Koeck, F. Miglior, G. Kistemaker, F. Schenkel, D. Kelton, and B. Van Doormaal. 2013. Genetic and genomic evaluation of mastitis resistance in Canada. Interbull Bull. 47:43-51.

Kadarmideen, H. N., R. Thompson, and G. Simm. 2000. Linear and threshold model genetic parameters for disease, fertility and milk production in dairy cattle. Anim. Sci. 71:411-419.

Koeck, A., F. Miglior, D. F. Kelton, and F. S. Schenkel. 2012a. Health recording in Canadian Holsteins: Data and genetic parameters. J. Dairy Sci. 95:4099-4108.

Koeck, A., F. Miglior, D. F. Kelton, and F. S. Schenkel. 2012b. Alternative somatic cell count traits to improve mastitis resistance in Canadian Holsteins. J. Dairy Sci. 95:432-439.

Koivula, M., E. Negussie, and E. A. Mäntysaari. 2004. Genetic parameters for test-day somatic cell count at different lactation stages of Finnish dairy cattle. Livest. Prod. Sci. 90:145-157.

Laevens, H., H. Deluyker, Y. H. Schukken, L. De Meulemeester, R. Vandermeersch, E. De Muelenaere, and A. De Kruif. 1997. Influence of parity and stage of lactation on the somatic cell count in bacteriologically negative dairy cows. J. Dairy Sci. 80:3219-3226.

Malchiodi, F., A. Koeck, S. Mason, A. M. Christen, D. F. Kelton, F. S. Schenkel, and F. Miglior. 2017. Genetic parameters for hoof health traits estimated with linear and threshold models using alternative cohorts. J. Dairy Sci. 100:2828-2836.

Miller, R. H., M. J. Paape, L. A. Fulton, and M. M. Schutz. 1993. The relationship of milk somatic cell count to milk yields for Holstein heifers after first calving. J. Dairy Sci. 76:728-733.

Naqvi, S. A., J. De Buck, S. Dufour, and H. W. Barkema. 2018. Udder health in Canadian dairy heifers during early lactation. J. Dairy Sci. 101:3233-3247.

Negussie, E., I. Strandén, and E. A. Mäntysaari. 2008. Genetic analysis of liability to clinical mastitis, with somatic cell score and production traits using bivariate threshold-linear and linear-linear models. Livest. Sci. 117:52-59.

Nyman, A. K., U. Emanuelson, K. Holtenius, K. L. Ingvartsen, K. L. Ingvartsen, and K. P. Waller. 2008. Metabolites and immune variables associated with somatic cell counts of primiparous dairy cows. J. Dairy Sci. 91:2996-3009.

Pyörälä, S. 2003. Indicators of inflammation in the diagnosis of mastitis. Vet. Res. 34:565-578.

Reichmuth. J. 1975. Somatic cell counting-Interpretation of results. Pages 93-109 in Proc. Seminar on Mastitis Control, 7-11 April. International Dairy Federation, Brussels, Belgium.
Renand, G., L. L. G. Janss, and J. Gaillard. 1990. Sire evaluation for direct effects on dystocia by linear and threshold models. Pages 465-467 in Proc. 4th World Congr. Genet. Appl. to Livest. Prod. Edinburgh 23-27 July 1990. XIII. Plenary Lect. Mol. Genet. Mapping, Sel. Predict. Estim. Edinburgh, Scotland, UK.

Reyher, K. K., S. Dufour, H. W. Barkema, L. Des Côteaux, T. J DeVries, I. R. Dohoo, G. P. Keefe, J.-P. Roy, and D. T. Scholl. 2011. The National Cohort of Dairy Farms - A data collection platform for mastitis research in Canada. J. Dairy Sci. 94:16161626.

Ruegg, P. L. 2017. A 100-year review: Mastitis detection, management, and prevention. J. Dairy Sci. 100:10381-10397.

Rupp, R., F. Beaudeau, and D. Boichard. 2000. Relationship between milk somatic-cell counts in the first lactation and clinical mastitis occurrence in the second lactation of French Holstein cows. Prev. Vet. Med. 46:99-111.

Saidi, R., D. Khelef, and R. Kaidi. 2013. Subclinical mastitis in cattle in Algeria: Frequency of occurrence and bacteriological isolates. J. S. Afr. Vet. Assoc. 84:E1-5.

Santman-Berends, I., and O. C. Sampimon. 2011. Subclinical mastitis in Dutch dairy heifers in early lactation and associated risk factors. Pages 325-330 in Udder Health and Communication. Wageningen Academic Publishers, Wageningen, the Netherlands.

SAS Institute. 2013. SAS 9.4 Guide to Software Updates. SAS Institute Inc., Cary, NC.

Schepers, A. J., T. J. G. M. Lam, Y. H. Schukken, J. B. M. Wilmink, and W. J. A. Hanekamp. 1997. Estimation of variance components for somatic cell counts to determine thresholds for uninfected quarters. J. Dairy Sci. 80:1833-1840.

Sheldrake, R. F., R. J. T. Hoare, and G. D. McGregor. 1983. Lactation stage, parity and infection affecting somatic cells, electrical conductivity and serum albumin in milk. J. Dairy Sci. 66:542-547.

Shook, G. E., and M. M. Schutz. 1994. Selection on somatic cell score to improve resistance to mastitis in the United States. J. Dairy Sci. 77:648-658.

Steeneveld, W., H. Hogeveen, H. W. Barkema, J. van den Broek, and R. B. M. Huirne. 2008. The influence of cow factors on the incidence of clinical mastitis in dairy cows. J. Dairy Sci. 91:1391-1402.

Svendsen, M., and B. Heringstad. 2006. Somatic cell count as an indicator of subclinical mastitis. Genetic parameters and correlations with clinical mastitis. Interbull Bull. 35:12-16.

Trinidad, P., S. C. Nickerson, and T. K. Alley. 1990. Prevalence of intramammary infection and teat canal colonization in unbred and primigravid dairy heifers. J. Dairy Sci. 73:107-114.

Urioste, J. I., J. Franzén, J. Windig, and E. Strandberg. 2012. Genetic relationships among mastitis and alternative somatic cell count traits in the first 3 lactations of Swedish Holsteins. J. Dairy Sci. 95:3428-3434

Wathes, D. C., Z. Cheng, W. Chowdhury, M. A. Fenwick, R. Fitzpatrick, D. G. Morris, J. Patton, and J. J. Murphy. 2009. Negative energy balance alters global gene expression and immune responses in the uterus of postpartum dairy cows. Physiol. Genomics 39:1-13. 